\title{
Rancang Bangun Pendeteksi Kualitas Minyak Goreng Kelapa Sawit dengan menggunakan Metode Sensor Ultrasonik dan Sensor Kapasitif Berbasis Smartphone
}

\author{
Cighra Satria Wibisono ${ }^{1}$, M. Nanak Zakaria ${ }^{2}$, Farida Arinie Soelistianto ${ }^{3}$ \\ 1,2,3 Program Studi Jaringan Telekomunikasi Digital, \\ Jurusan Teknik Elektro, Politeknik Negeri Malang, Indonesia \\ 1. cighrasatria1998@gmail.com, ${ }^{2}$ nanak712000@gmail.com, ${ }^{3}$ farida.arinie@polinema.ac.id
}

\begin{abstract}
In this study the application can be used so that consumers can find out the fat content and acidity in barco oil, fish dorang, and bulk oil which has an android monitoring system in real time. This research uses Arduino uno and Node MCU as the microcontroller. Arduino Uno will later be assembled together with water $\mathbf{p H}$ modules, ultrasonic HC-SR04, and capacitive soil. The pH module functions to measure the water and fat content in palm oil. Ultrasonic module that functions to measure the volume of the oil measurement container. The capacitive module is used to determine the density of quality in saturated oil. The test results can be concluded that the pH sensor can detect levels of fat and acidity in palm oil has a value of about 5 to 11 . Ultrasonic sensors on the volume of oil samples of barco and fish dorang have a significantly increased grapH, while the bulk oil sample has a very high grapH which causes acidity oil. This study has the highest delay of $1.303525 \mathrm{~ms}$ and the lowest delay of $0.628276 \mathrm{~ms}$. With an average value of delay obtained of $1.189657 \mathrm{~ms}$.
\end{abstract}

Keywords - Capacitive, Delay, Palm oil, pH, Ultrasonic

Abstrak-Pada penelitian ini aplikasi andoid dapat digunakan sebagai alat bantu konsumen mengetahui kadar lemak dan keasaman pada minyak barco,ikan dorang,dan minyak curah yang memiliki sistem monitoring secara real time. Penelitian ini menggunakan Arduino uno dan NodeMCU sebagai mikrokontrollernya. Arduino uno nantinya akan dirangkainya bersama dengan modul pH air,ultrasonik HC-SR04,dan kapasitif soil. Modul pH berfungsi untuk mengukur kadar air dan lemak pada minyak sawit. Modul ultrasonik yang berfungsi untuk mengukur volume pada wadah pengukuran minyak. Modul kapasitif berfungsi untuk menentukan kepadatan kualitas pada minyak jenuh. Hasil pengujian dapat disimpulkan bahwa Sensor pH dapat mendeteksi kadar lemak dan keasaman pada minyak sawit memiliki nilai sekitar 5 sampai 11. Sensor ultrasonik pada volume minyak sampel barco dan ikan dorang memiliki grafik yang signifikan naik,sedangkan sampel minyak curah memiliki grafik yang sangat tinggi yang menyebabkan keasaman minyak. Penelitian ini memiliki delay tertinggi sebesar $1.303525 \mathrm{~ms}$ dan delay terendah sebesar 0,628276ms. Dengan nilai rata-rata delay yang didapatkan sebesar $1.189657 \mathrm{~ms}$.

Kata kunci-Delay, Kapasitif, Minyak Sawit, pH, Ultrasonik

\section{PENDAHULUAN}

Di negara kita pertanian atau perkebunan merupakan sumber utama dalam memenuhi kebutuhan pangan. Kelapa sawit sebagai tanaman penghasil minyak sawit dan inti sawit merupakan salah satu primadona tanaman perkebunan yang menjadi sumber penghasil devisa non migas bagi Indonesia. Minyak sawit merupakan salah satu dari 17 jenis minyak dan lemak dunia dengan kontribusi mencapai $27,8 \%$ di Indonesia sebagai penghasil minyak sawit terbesar dunia telah berkontribusi untuk mengisi kebutuhan minyak sawit dunia. Crude palm oil (CPO) Indonesia mencapai 21 juta ton dan diperkirakan terus meningkat sampai tahun mencapai 22,2 juta ton. Sebagai fakta, CPO Indonesia menjadi salah satu komoditi ekspor yang menambah devisa negara selain migas[1].

Bagian yang paling utama untuk diolah dari kelapa sawit adalah buahnya. Bagian daging buah menghasilkan minyak kelapa sawit mentah yang diolah menjadi bahan baku minyak goreng. Kelebihan minyak nabati dari sawit adalah harga yang murah, rendah kolesterol, dan memiliki kandungan karoten tinggi. Minyak sawit juga diolah menjadi bahan baku margarin. Keberadaan orang yang sudah usia muda maupun usia lanjut seharusnya dapat memberikan informasi mengenai betapa pentingnya upaya dalam membeli atau memilih minyak goreng yang baik secara kadar lemak maupun keasamannya[2].

Permasalahan yang sering dialami konsumen atau pembeli adalah tingkat kesulitan yang cukup tinggi yaitu kurangnya pengetahuan tentang kadar lemak dan keasaman pada minyak goreng kelapa sawit [3]. Konsumen pasti akan lebih paham atau mengerti tentang kadar lemak dan keasaman pada minyak goreng kelapa sawit ketika ingin membeli atau mengosumsi minyak tersebut [4][5].

Penelitian tersebut dapat digunakan untuk konsumen mengetahui kandungan lemak pada minyak kelapa Barco, Ikan Dorang, dan Curah[6]. Pada penelitian ini menggunakan 
Arduino uno dan NodeMCU sebagai mikrokontrollernya. Arduino uno nantinya akan dirangkainya bersama dengan modul $\mathrm{pH}$ air, ultrasonic HC-SR04, dan kapasitif soil[7]. Modul $\mathrm{pH}$ berfungsi untuk mengukur kadar air dan lemak pada minyak sawit[8][9]. Modul ultrasonic yang berfungsi untuk mengukur volume pada wadah pengukuran[10]. Modul kapasitif berfungsi untuk menentukan kepadatan kualitas pada minyak jenuh. Data ini akan dikirimkan dan disimpan pada database yang digunakan, yaitu Firebase Database[11].

\section{METODE}

\section{A. Rancangan Penelitian}

Rancangan yang akan digunakan dalam penelitian penelitian adalah pembuatan tahap-tahap pencarian informasi, pembuatan alat hingga pengujian, dalam skripsi yang disusun dengan maksud agar penelitian dilakukan secara terperinci dan terencana melalui tahap-tahap yang telah disusun sebelumnya, ditunjukkan pada Gambar 1.

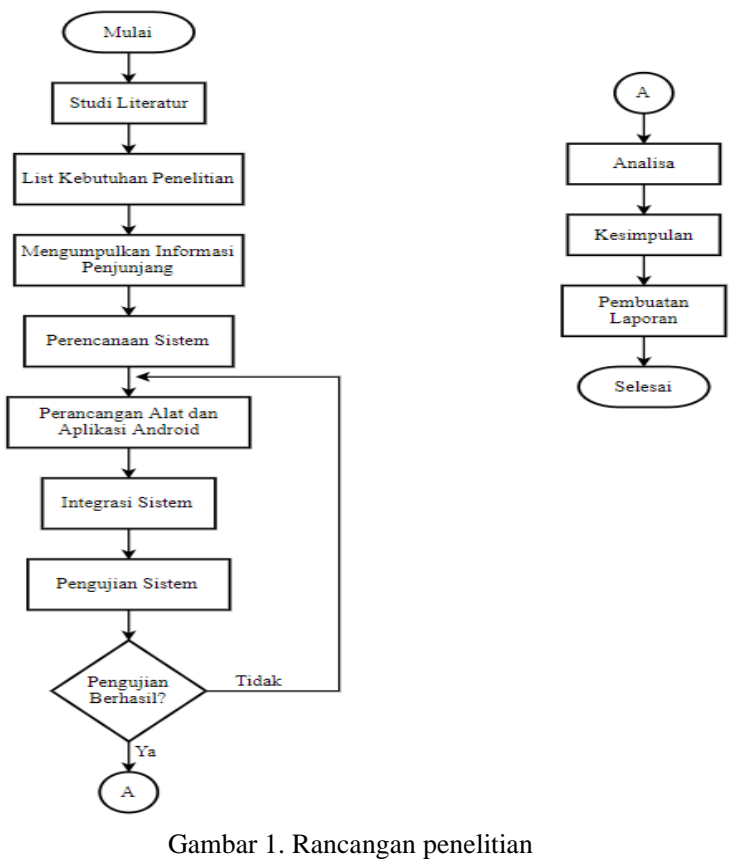

Langkah pertama studi literatur mengenai Jenis minyak kelapa, Arduino Uno, NodeMCU, Sensor Kapasitif, Sensor pH, Sensor Ultrasonik Firebase, Aplikasi Android, komunikasi data pada sistem, dan lainnya. Pada tahap ini, ditentukan spesifikasi alat dan bahan, pemrograman yang digunakan, dan sistem komunikasi yang digunakan.

Langkah kedua melakukan list kebutuhan penelitian merupakan tahapan untuk menentukan kebutuhan perangkat seperti komponen, hardware, dan software pada penelitian yang akan dilakukan.

Langkah ketiga tahapan mengumpulkan informasi penunjang merupakan kegiatan untuk memperkuat pengetahuan sebagai landasan dalam melakukan penelitian yang akan dilakukan.

Langkah keempat perencanaan sistem membahas tentang perencanaan dan pembuatan desain perangkat dari sistem.
Diantaranya, desain alat, pemrograman android, serta perkiraan letak perangkat yang digunakan.

Langkah kelima dalam penelitian ini akan dibuat alat untuk mendeteksi lokasi keberadaan lansia menggunakan microcontroller, serta pemanfaatan $\mathrm{pH}$, Kapasitif, Ultrasonik yang akan diterapkan teknologinya di aplikasi android.

Langkah keenam pada tahap ini alat yang dibuat akan diintegrasikan atau dihubungkan dengan aplikasi android sesuai dengan perencanaan sistem yang sudah dibuat.

Langkah ketujuh sistem yang telah dibuat sebelumnya, akan dilakukan uji coba apakah sistem yang telah dibuat memiliki hasil yang sesuai dengan harapan atau tidak. Jika tidak, akan dilakukan perencanaan sistem kembali.

Langkah kedelapan analisa sistem yang telah diuji diantaranya alat dan program dapat berjalan dengan sesuai, antara alat dan aplikasi dapat menerapkan keakuratan data yang dihasilkan dari alat yang dibuat.

Langkah kesembilan pada tahap ini merupakan pembuatan kesimpulan yang diambil berdasarkan rumusan masalah, pembutanan sistem serta hasil pengujian dan analisa yang dilakukan.

Langkah kesepuluh setelah analisa sistem dan kesimpulan selesai, maka dibuatkan laporan penelitian

\section{B. Perencanaan Sistem}

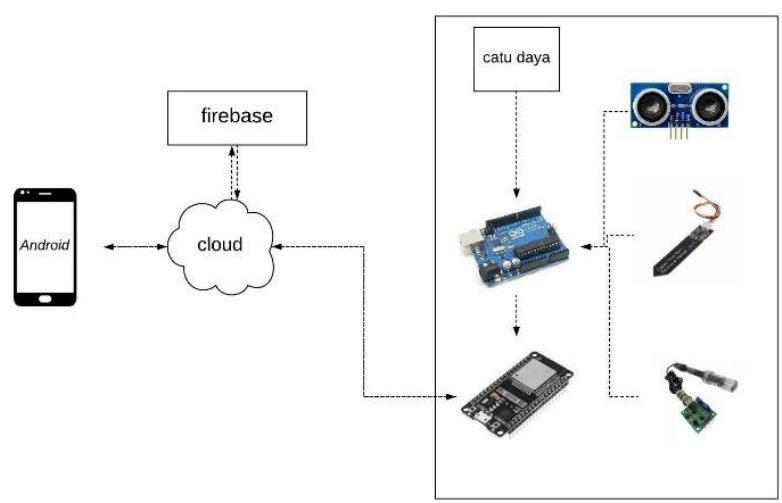

Gambar 2. Perencanaan sistem

Perancangan sistem yang dilakukan selama penelitian, keterangan dari Gambar 2 adalah sebagai mikrokontroler Arduino uno yang akan terhubung dengan 3 jenis sensor yaitu sensor ultrasonik,sensor kapasitif dan sensor $\mathrm{pH}$ dan juga tersambung modul Node MCU yang nantinya data pada percobaan akan dikirim kan dengan komunikasi internet ke database server (Firebase), setelah itu data yang dikirimkan menuju smartpHone/android dan ditampilkan pada aplikasi android yang terintergrasi database server (Firebase) dengan koneksi internet pada konsumen.

\section{HASIL DAN PEMBAHASAN}

Hasil penelitian hendaknya dituliskan secara jelas dan padat. Diskusi hendaknya menguraikan arti pentingnya hasil penelitian, bukan mengulanginya. Hindari penggunaan sitasi dan diskusi yang berlebihan tentang literatur yang telah dipublikasikan. 


\section{A. Hasil Implementasi Alat}

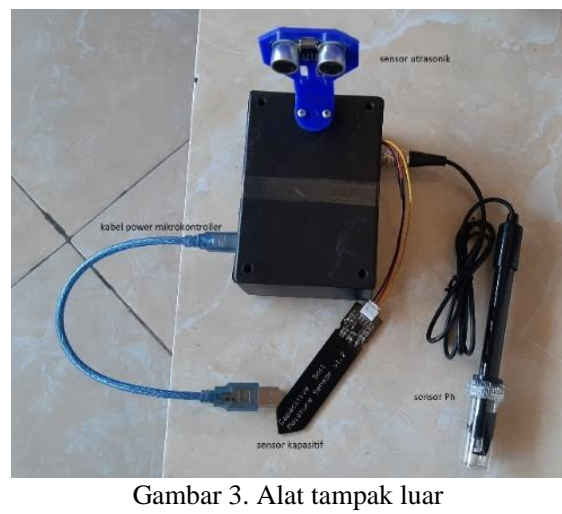

Tampilan rangkaian mikrokontroler digunakan untuk memproses pemrograman sensor dan NodeMCU mengatur pengiriman data parameter kondisi minyak ke database server, alat tampak luar ditunjukkan pada Gambar 3. Kalibrator $\mathrm{pH}$ digunakan untuk menstabilkan keluaran parameter nilai pada sensor $\mathrm{pH}$, sensor ultrasonic digunakan untuk mengukur kadar air pada sampel minyak, dan sensor kapasitif digunakan untuk mengukur kepadatan pada unsur minyak kelapa. Tampak dalam alat ditunjukkan pada Gambar 4.

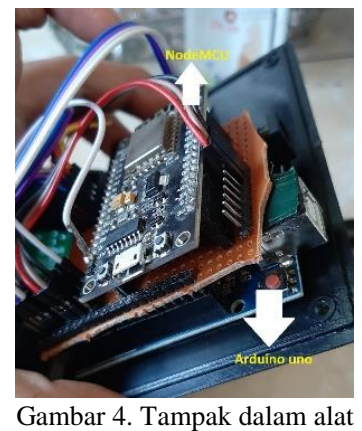

\section{B. Hasil Implementasi Aplikasi Android}

Hasil implementasi aplikasi berupa desain tampilan utama aplikasi pemantauan kondisi kualitas pada sampel minyak kelapa yang telah dibuat yang ditunjukkan Gambar 5. Data hasil minyak kelapa dan curah ditunjukkan pada Gambar 6.

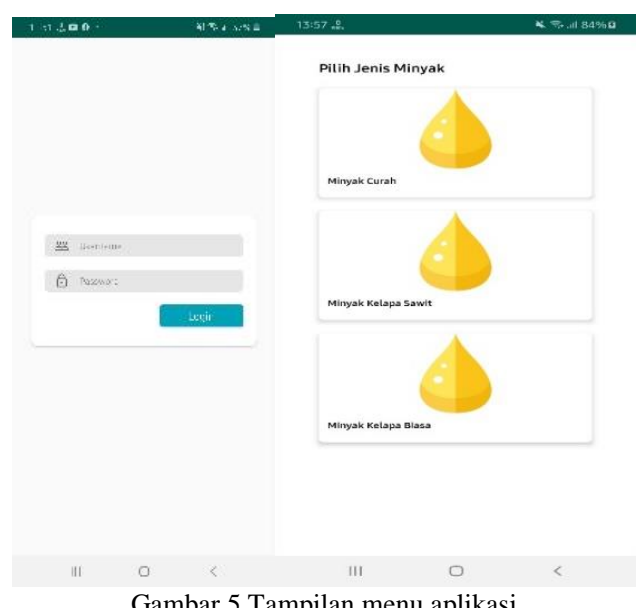

Gambar 5 Tampilan menu aplikasi

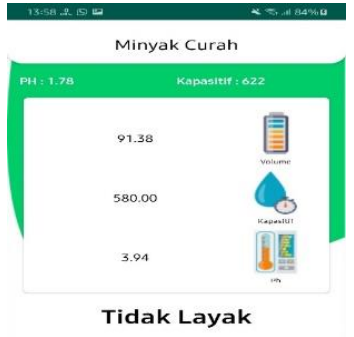

Gambar 6. Data hasil minyak kelapa dan curah

C. Pengujian Alat Sensor pada Sampel Minyak

TABEL I.

PENGUJIAN MENGGUNAKAN SENSOR PH

\begin{tabular}{cccc}
\hline Per menit & Minyak Barco & Minyak Dorang & Minyak curah \\
\hline 1 & 3.21 & 2.68 & 1 \\
2 & 2.03 & 2.84 & 1.58 \\
3 & 3.32 & 2.14 & 1.7 \\
4 & 2.06 & 3.12 & 0.97 \\
5 & 3.38 & 2.12 & 0.97 \\
6 & 2 & 3.12 & 1.72 \\
7 & 3.38 & 1.95 & 1.78 \\
8 & 2.09 & 3.18 & 0.88 \\
9 & 3.32 & 2.17 & 1.78 \\
10 & 2.2 & 3.1 & 2.09 \\
\hline
\end{tabular}

Tabel I menunjukkan hasil yang berbeda untuk pengkalibrasian minyak menggunakan sensor $\mathrm{pH}$. Minyak Barco memiliki tabel secara terus menerus dengan nilai yang tidak berubah ubah dengan nilai teringgi 3.38 dan terendah 2 . Ikan dorang memiliki tabel yang berbeda dengan sampel barco yaitu nilai pada sampel terebut tidak terjadi kenaikan yang sangat drastis dengan nilai tertinggi 3.18 dan terendah 1.95 . Sedangkan tabel dari minyak curah memiliki nilai yang sangat tidak bagus dengan nilai terendah 0.97 dan tertinggi 1.78 .

TABEL II.

PENGUJIAN MENGGUNAKAN SENSOR PH SAMPEL MiNYAK KELAPA DENGAN

\begin{tabular}{cccc}
\hline \multicolumn{3}{c}{ AQUADES } \\
$\begin{array}{c}\text { Per 1 } \\
\text { minutes }\end{array}$ & $\begin{array}{c}\text { Minyak } \\
\text { barco }\end{array}$ & $\begin{array}{c}\text { Minyak ikan } \\
\text { dorang }\end{array}$ & $\begin{array}{c}\text { Minyak } \\
\text { curah }\end{array}$ \\
\hline 1 & 6.06 & 5.76 & 12.7 \\
2 & 5.78 & 5.73 & 2.51 \\
3 & 5.92 & 5.81 & 11.75 \\
4 & 5.9 & 5.87 & 2.84 \\
5 & 5.92 & 5.87 & 7.16 \\
6 & 5.92 & 5.87 & 8 \\
7 & 5.87 & 5.9 & 11.97 \\
8 & 5.9 & 5.92 & 11.27 \\
9 & 5.84 & 5.95 & 8.08 \\
10 & 5.87 & 5.95 & 2.23 \\
\hline
\end{tabular}

Tabel II pengukuran $\mathrm{pH}$ dengan sampel minyak A, B, C, dan pencampuran aquades yang dapat mengetahui kadar lemak dan keasaman pada minyak sawit. Pada kandungan minyak yang layak konsumsi untuk konsumen yaitu memiliki nilai mutu sebesar 5 sampai 11, bila dalam kandungan minyak tersebut melebihi nilai mutu maka minyak sawit tersebut kurang baik untuk dikonsumsi. 
TABEL III.

PENGUJIAN MENGGUNAKAN SENSOR ULTRASONIK

\begin{tabular}{ccccc}
\hline Menit & Volume & Minyak Barco & Minyak Ikan Dorang & Minyak Curah \\
\hline 10 & $10 \mathrm{ml}$ & 68.11 & 74.08 & 7.08 \\
10 & $20 \mathrm{ml}$ & 74.86 & 85.65 & 111.28 \\
10 & $30 \mathrm{ml}$ & 66.74 & 66.77 & 99.38 \\
10 & $40 \mathrm{ml}$ & 103.3 & 96.44 & 105.54 \\
10 & $50 \mathrm{ml}$ & 85.65 & 93.74 & 96.1 \\
10 & $60 \mathrm{ml}$ & 101.53 & 97.11 & 111.61 \\
10 & $70 \mathrm{ml}$ & 96.14 & 95.74 & 65.75 \\
10 & $80 \mathrm{ml}$ & 99.47 & 103.18 & 104.87 \\
10 & $90 \mathrm{ml}$ & 104.53 & 93.74 & 111.28 \\
10 & $100 \mathrm{ml}$ & 106.55 & 91.38 & 111.61 \\
\hline
\end{tabular}

Tabel pengukuran pada volume minyak sampel barco, ikan dorang, dan curah yang terjadi penguapan pada minyak setelah pemanfaatan cahaya sinar matahari. Pada perhitungan pengujian tersebut telihat macam-macam kadar air pada sampel minyak kelapa maupun tidak, ditunjukkan pada Tabel III.

TABEL IV

PENGUJian MENGgunaKan SENSOR KAPASITIF

\begin{tabular}{cccc}
\hline Per menit & Barco & Ikan Dorang & curah \\
\hline 10 & 5,85 & 5,82 & 6,22 \\
10 & 5,85 & 5,81 & 6,37 \\
10 & 5,84 & 5,82 & 6,22 \\
10 & 5,83 & 5,82 & 6,24 \\
10 & 5,85 & 5,80 & 6,25 \\
10 & 5,85 & 5,82 & 6,20 \\
10 & 5,84 & 5,83 & 6,22 \\
10 & 5,85 & 5,82 & 6,22 \\
10 & 5,82 & 5,82 & 6,28 \\
10 & 5,85 & 5,8 & 6,22 \\
\hline
\end{tabular}

Hasil dari pengujian dengan sensor kapasitif yang menunjukan bahwa semakin nilai kapasitif minyak semakin tinggi maka kepadatan lemak juga semakin tinggi yang ditunjukkan pada Tabel IV.

\section{KESIMPULAN}

Kandungan lemak pada minyak kelapa dengan menggunakan sensor $\mathrm{pH}$ sampel Barco sebesar 5,92\%, Ikan Dorang 5,87\%, dan Curah 11,97\%. Pada sensor kapasitif kandungan lemak pada minyak kelapa menunjukan nilai hasil sebesar $5,85 \mu \mathrm{F}$ sedangkan hasil minyak curah sebesar $6,22 \mu \mathrm{F}$ dapat disimpulkan bahwa nilai kapasitif semakin tinggi maka kepadatan lemak tinggi.

Perbandingan kandungan air pada kualitas minyak kelapa dengan sensor ultrasonik memiliki nilai pada sampel barco sebesar 106,55\%, Ikan Dorang 91,38\%, dan Curah 111,61\%.

Pada sistem kualitas minyak kelapa menggunakan aplikasi android yang digunakan pada alat pengukuran $\mathrm{pH}$,volume, dan kapasitif yang langsung kepada konsumen secara real time dengan memiliki delay tertinggi sebesar $1.303525 \mathrm{~ms}$ dan delay terendah sebesar $0,628276 \mathrm{~ms}$. Dengan nilai rata-rata delay yang didapatkan sebesar $1.189657 \mathrm{~ms}$.

\section{REFERENSI}

[1] H. A. Hasibuan, "Kajian Mutu Dan Karakteristik Minyak Sawit Indonesia Serta Produk Fraksinasinya," J. Stand., vol. 14, no. 1, p. 13, 2012.

[2] I. F. Ulfindrayani and Q. A'yuni, "Penentuan Kadar Asam Lemak Bebas Dan Kadar Air Pada Minyak Goreng Yang Digunakan Oleh Pedagang Gorengan Di Jalan Manyar Sabrangan, Mulyorejo, Surabaya," J. PHarm. Sci., vol. 3, no. 2, pp. 17-22, 2018.

[3] S. Jenderal, "The war dan practical dietetics," J. Am. Med. Assoc., vol. LXV, no. 1, pp. 31-33, 2007.

[4] B. A. B. Ii dan T. Pustaka, "Crude Palm Oil (CPO) atau minyak kelapa sawit," pp. 3-19, 2004.

[5] A. L. Belakang, "minyak kelapa murni," pp. 1-55, 2004.

[6] M. Wuri Marsigit, "Analisis Penurunan Kualitas Minyak Goreng Curah Selama Penggorengan Kerupuk Jalin," J. Chem. Inf. Model., vol. 53, no. 9, pp. 1689-1699, 2013.

[7] S. Samsugi, A. Ardiansyah, dan D. Kastutara, "Arduino dan Modul Wifi ESP8266 sebagai Media Kendali Jarak Jauh dengan antarmuka Berbasis Android," J. Teknoinfo, vol. 12, no. 1, p. 23, 2018.

[8] Z. S. Putra, M. Rivai, dan S. Suwito, "Sistem sensor kualitas minyak berdasarkan pada pengukuran kapasitansi dan panjang berkas pembiasan cahaya," $J$. Tek. ITS, vol. 2, no. 1, pp. B67-B72, 2013.

[9] E. Ihsanto dan S. Hidayat, "Rancang Bangun Sistem Pengukuran $\mathrm{Ph}$ Meter Dengan Menggunakan Mikrokontroller Arduino Uno," J. Teknol. Elektro, vol. 5, no. 3, 2014.

[10] M. D. Supardan, "Penggunaan Ultrasonik untuk Transesterifikasi Minyak Goreng Bekas," J. Rekayasa Kim. Lingkung., vol. 8, no. 1, pp. 11-16, 2011.

[11] G. R. Paraya dan R. Tanone, "Penerapan Firebase Realtime Database Pada Prototype Aplikasi Pemesanan Makanan Berbasis Android," J. Tek. Inform. dan Sist. Inf., vol. 4, no. 3, pp. 397-406, 2018 